Journal of Southeast Asian

\title{
Book Review: This Is All I Choose to Tell: History and Hybridity in Vietnamese American Literature, by Isabelle Thuy Palaud
}

Bryan Thao Worra

Lao Assistance Center, thaoworra@aol.com

Follow this and additional works at: https://docs.lib.purdue.edu/jsaaea

\section{Recommended Citation}

Worra, Bryan Thao (2012) "Book Review: This Is All I Choose to Tell: History and Hybridity in Vietnamese American Literature, by Isabelle Thuy Palaud," Journal of Southeast Asian American Education and Advancement: Vol. 7 : Iss. 1, Article 6.

DOI: $10.7771 / 2153-8999.1048$

Available at: https://docs.lib.purdue.edu/jsaaea/vol7/iss1/6

This document has been made available through Purdue e-Pubs, a service of the Purdue University Libraries. Please contact epubs@purdue.edu for additional information.

This is an Open Access journal. This means that it uses a funding model that does not charge readers or their institutions for access. Readers may freely read, download, copy, distribute, print, search, or link to the full texts of articles. This journal is covered under the CC BY-NC-ND license. 


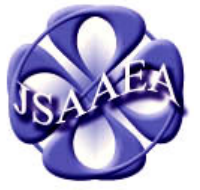

Volume 7 (2012)
Journal of Southeast Asian American Education \& Advancement WWW.JSAAEA.org
A peer-reviewed scholarly journal published by the National Association for the Education \& Advancement of Cambodian, Laotian, and Vietnamese Americans (NAFEA)

\title{
Pelaud, Isabelle Thuy. (2011). This is all I choose to tell: History and hybridity in Vietnamese American literature. Philadelphia: Temple University Press. 216 pp. \$22.95 (Paperback). ISBN: 978-1439902172.
}

\author{
Reviewed by \\ Bryan Thao Worra \\ Journal of Southeast Asian American Education and Advancement
}

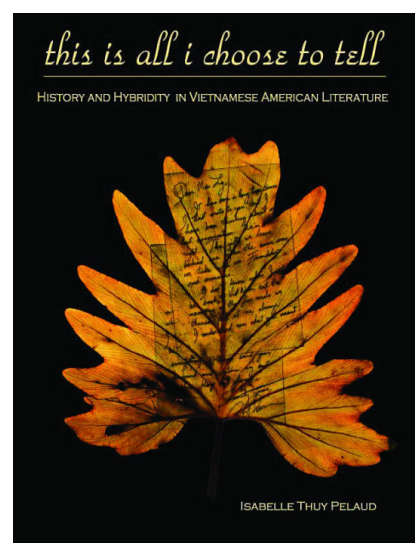

Writing about any community's literature is an exercise in trying to hit a moving target. This particularly applies to the writing of Southeast Asian refugee communities in America. Their expressive voices are often thoroughly intertwined with their personal and collective histories and traditions. The writers and their audiences are working to navigate several different spaces, influenced by geography, education, the size of their communities and their relationship to their language and traditional and contemporary art forms.

Stepping into the middle of all of this for the Vietnamese American community is Isabelle Thuy Pelaud's This Is All I Choose To Tell from Temple University Press. Positioned as the first book-length study of Vietnamese American literature, the book aims to examine the connection between identity, politics and literature. It's an ambitious effort that Pelaud breaks into two parts, "Inclusion" and "Interpretation" to approach the last 35 years of the Vietnamese American voice.

She approaches it with an understanding that there was a fine line between representation and replicating the logic of domination. It is clear that she hoped to provide educators a starting text to consider interesting ways to understand and present Vietnamese American texts in their courses, cognizant of the contexts in which they emerged, but also with an appreciation for their diversity. Many of the texts Pelaud found in her studies were concerned with remembrance, often with a sense of the Vietnam War, and how the communities and authors were crafting a new sense of home. Pelaud explores how many of the writers also want to define Vietnamese American culture and its experience beyond the war, despite its marketability to publishers and much of today's audiences.

Pelaud writes, "How one interprets and reads Vietnamese American literature, or any literature, is political in nature" (p. 42). This is a theme she will revisit throughout the text as she examines examples of poetry, short story, creative non-fiction, novels and memoirs. There are

SOMEREIGHISRESEREED Readers are free to copy, display, and distribute this article, as long as the work is attributed to the author(s) and the Journal of Southeast Asian American Education \& Advancement, it is distributed for noncommercial purposes only, and no alteration or transformation is made in the work. More details of this Creative Commons license are available at http://creativecommons.org/licenses/by-nc-nd/3.0/. All other uses must be approved by the author(s) or JSAAEA. 
many insightful examinations regarding Andrew Pham's Catfish and Mandala, the work of Linh Dinh, Barbara Tran, Monique Truong, Bao Phi and many other established and emerging writers in the Vietnamese American community. She looks at not only how their works were written and what they suggest about the emerging and shifting Vietnamese American identity, but also how they were received.

Pelaud notes that a significant amount of the literature today tends to hold back for a variety of reasons, including the purpose of protecting the living. Fiction is also not seen as common, but she anticipates that in the future, "the notion of home will become more entangled with the living" (p. 137).

Throughout This Is All I Choose to Tell, it is clear she is familiar with the history and journey of Vietnamese American writers, writing with great enthusiasm and passion for the subject while committed to rigorous, but readable scholarship.

Part One, "Inclusion," is composed of three chapters: Overview, History and Hybridity. It is an able section examining the questions of where Vietnamese Americans belong within a historic context as both physical residents and literary artists. Pelaud lays out the idea that Vietnamese American history and literature will not automatically veer towards an "inevitable attraction toward Anglo-Saxon culture" (p. 20). Readers will find a satisfying introduction to the journey of Vietnamese Americans publication, from the early collaborations with white writers to the early anthologies and current publishing trends, notably Monique Truong's The Book of Salt.

Part Two, "Interpretation," is constructed of three chapters on Survival, Hope and Despair, and Reception. Here is where the book begins to really soar, as she proposes key ways for emerging scholars, educators and general readers to appreciate the often complex themes and subthemes interwoven into different texts by Vietnamese American writers.

This Is All I Choose To Tell does not go into extensive details of the larger artistic ecosystems the Vietnamese American communities are developing, such as the role of community members to preserve and occasionally update Vietnamese dance, theater, painting, photography and other art forms. This does not strictly hamper Pelaud's arguments, but even as the book discusses hybridity, a full appreciation of the Vietnamese American community's expressive voice should probably look at the intermedia aspects of this journey. This would be helpful for readers considering recent examples such as the Eisner-nominated Vietnamerica, a 2011 memoir presented as a graphic novel.

Much of This Is All I Choose To Tell allows us to consider that what we say and how we say it is important, but that in assessing Vietnamese American and other Southeast Asian American literature, what we do not say, and how we do not say these things is also important to consider.

In the final assessment, this is a groundbreaking book regarding Vietnamese American issues in their emerging literature. As a preliminary introduction to Vietnamese American literature and culture, it will appeal to scholars and many of their students, and many of the issues Pelaud raises have parallels for the Cambodian, Lao, Hmong and other communities who came to the U.S. as refugees. This is certainly not the last word on the subject, but it is a compelling beginning to consider. 


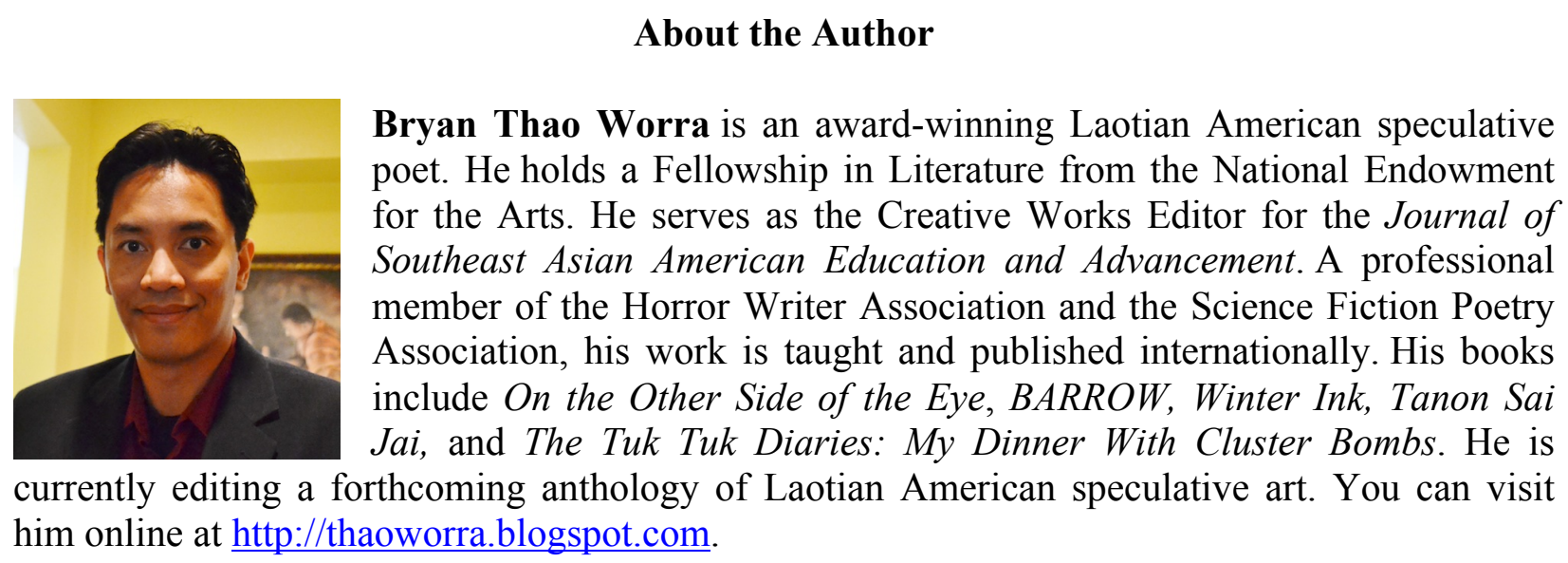




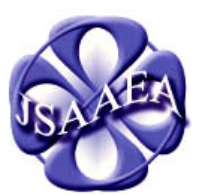

Volume 7 (2012)

\section{Journal of Southeast Asian American Education \& Advancement}

\author{
WwW.JSAAEA.org
}

\section{Editor}

Dr. Wayne E. Wright

University of Texas, San Antonio

\author{
Associate Editors \\ Dr. Chhany Sak-Humphry \\ University of Hawaii at Manoa
}

Dr. Phitsamay Sychitkokhong Uy

University of Massachusetts, Lowell

\section{Book Review Editor}

Dr. Vichet Chhuon

University of Minnesota

\section{Creative Works Editor \\ Bryan Thao Worra \\ Lao Assistance Center}

Special Advisor

Gregory Green

Curator, Echols Collection on Southeast Asia, Cornell University Library

\section{Journal Manager}

Sovicheth Boun

University of Texas, San Antonio
A peer-reviewed scholarly journal published by the

National Association

for the Education \&

Advancement of

Cambodian, Laotian,

and Vietnamese

Americans (NAFEA)

Comments and questions for the editorial staff may be directed to jsaaea@1ists.sis.utsa.edu

\section{Editorial Review Board}

\author{
Dr. Steve Arounsack \\ California State University, Stanislaus \\ Dr. Phala Chea \\ Lowell Public Schools \\ Dr. Loan Dao \\ Cancer Prevention Institute of California \\ Dr. Changming Duan \\ University of Missouri, Kansas City \\ Dr. Jeremy Hein \\ University of Wisconsin - Eau Claire \\ Dr. Samlong Inthaly \\ Minneapolis Public Schools \\ Dr. Kevin K. Kumashiro \\ University of Illinois, Chicago
}

Dr. Carl L. Bankston III

Tulane University

Dr. George Chigas

University of Massachusetts, Lowell

Dr. Hien Duc Do

San Jose State University

Dr. Sophal Ear

U.S. Naval Postgraduate School

Dr. Nancy H. Hornberger

University of Pennsylvania

Dr. Peter Nien-Chu Kiang

University of Massachusetts, Boston

Dr. Ha Lam

Arizona State University 


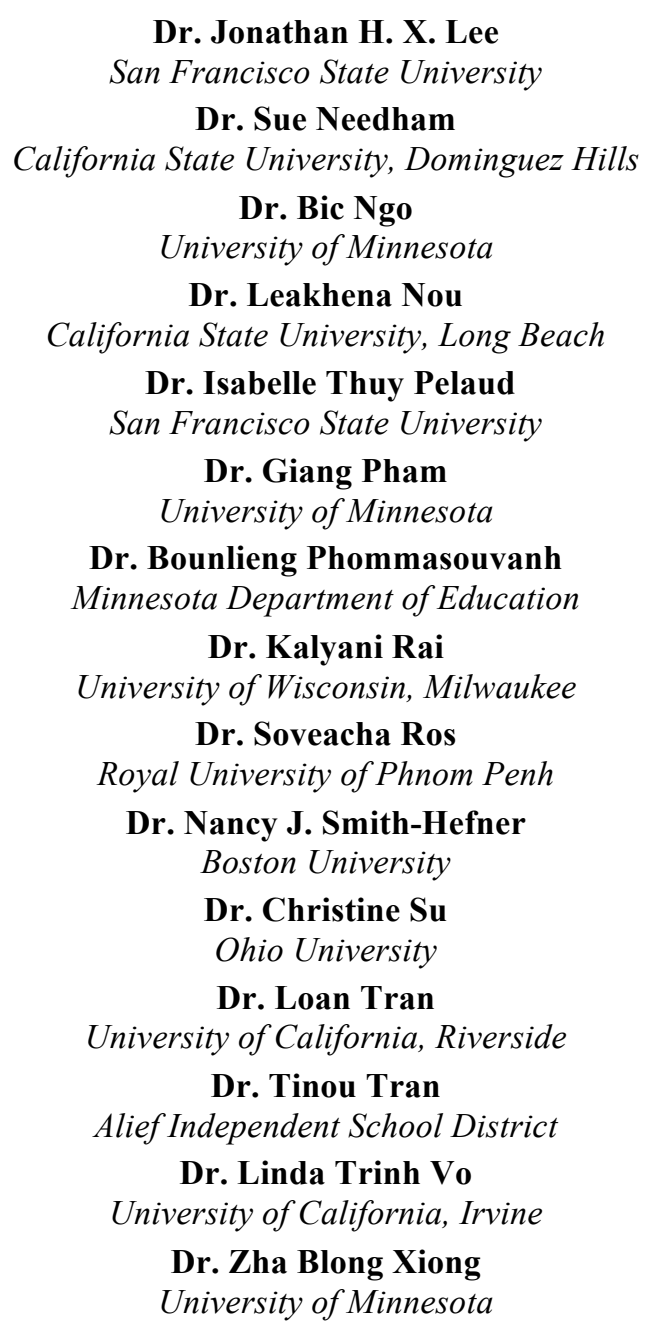

Dr. Jonathan H. X. Lee

Dr. Sue Needham

Dr. Bic Ngo

Unersity of Minnesota

ia State University, Long Beach

Dr. Isabelle Thuy Pelaud

Dr. Giang Pham

University of Minnesota

Dr. Bounlieng Phommasouvanh

Dr. Kalyani Rai

Dr. Soveacha Ros

Royal University of Phnom Penh

Boston University

Dr. Christine Su

Ohio University

Dr. Tinou Tran

Dr. Linda Trinh Vo

University of Minnesota

\author{
Dr. Stacey Lee \\ University of Wisconsin, Madison \\ KimOanh Nguyen-Lam \\ U.S. Department of Education \\ Dr. Max Niedzwiecki \\ Daylight Consulting Group \\ Dr. Clara Park \\ California State University, Northridge \\ Dr. Mark Pfeifer \\ SUNY Institute of Technology \\ Dr. Loan T. Phan \\ University of New Hampshire \\ Dr. Karen Quintiliani \\ California State University, Long Beach \\ Dr. Angela Reyes \\ Hunter College, The City University of New York \\ Dr. Fay Shin \\ California State University, Long Beach \\ Dr. Cathy J. Schlund-Vials \\ University of Connecticut, Storrs \\ Dr. Yer J. Thao \\ Portland State University \\ Dr. Myluong Tran \\ San Diego State University \\ Dr. Khatharya Um \\ University of California, Berkeley \\ Dr. Terrence G. Wiley \\ Center for Applied Linguistics \\ Dr. Kou Yang \\ California State University, Stanislaus
}

\section{Doctoral Student Editorial Review Board}

\author{
Keo Chea-Young \\ University of Pennsylvania \\ Ketmani Kouanchao \\ California State University, Fullerton \\ Ravy Lao \\ University of California, Santa Barbara \\ Thien-Huong Ninh \\ University of Southern California \\ Vanna Som \\ Harvard University \\ Krissyvan Truong \\ Claremount Graduate University \\ Yang Sao Xiong \\ University of California, Los Angeles
}

\author{
Annie BichLoan Duong \\ San Joaquin County Office of Education \\ Peter Tan Keo \\ Columbia University \\ Monirith Ly \\ Texas State University-San Marcos \\ Malaphone Phommasa \\ University of California, Santa Barbara \\ Alisia Tran \\ University of Minnesota \\ Silvy Un \\ University of Minnesota \\ Yeng Yang \\ University of Texas, San Antonio
}

